\title{
Analysis on Characteristics of Effective Agricultural Land System in China after the Founding of PRC
}

\author{
Xin Shang \\ School of Economics \& Management, Changchun University of Science and Technology \\ Changchun 130022, China \\ E-mail: shangxin401@163.com \\ Shanshuo Zhao \\ School of Economics \& Management, Changchun University of Science and Technology \\ Changchun 130022, China
}

\begin{abstract}
This article makes an analysis on effective agricultural land system in China after the founding of PRC from the three aspects of its root cause, incentive mechanism and assets rights of farmers. According to the authors, at the stage of low economic development, we should carry out agricultural land system through improving the incentive mechanism and enlarging assets rights of farmers, etc. Agricultural land systems with different efficiency differ from each other in the following aspects: whether peasant households really own the property right and whether their internal incentive mechanism can be brought into play to mobilize the enthusiasm of producers.
\end{abstract}

Keywords: Effective agricultural land system, Incentive mechanism, Assets rights

In essence, agricultural land system, as relations of production, embodies relationship between various factors of agricultural production and reflects the status of all stakeholders in agriculture, which forms the hierarchical relationship of interests in agricultural production and then affects the economic behavior of people in agricultural production. When an agricultural land system is appropriate for the level of productivity development, agricultural land system will facilitate increase of agricultural efficiency; on the contrary, the agricultural land system will hinder agricultural efficiency. After the founding of PRC, agricultural land system in China has undergone the evolvement process of three states, including private land ownership, collective land system and rural household contract responsibility system, and the agricultural development level under different agricultural land systems also exhibit remarkable variations. The congruent relationship between Chinese agricultural system and agricultural performance once again verifies the important effect of a system on economic development. Just as North said (Douglass North, 2008), “A system plays a more elementary role in a society, and is the fundamental factor to decide long term economic performance." This article assumes, an agricultural land system can facilitate increase of agricultural productivity on a large scale, which means that this agricultural land system is effective, namely, an effective agricultural land system. In contrast, if the agricultural productivity under the system is low, then this agricultural land system is inefficient, namely, inefficient agricultural land system. The agricultural productivity here is measured by the index of agricultural gross output value for the following two reasons: firstly, agricultural gross output value is one of the basic indices to measure agricultural productivity; secondly, it is difficult to get access to comprehensive agricultural production data, whereas the index of agricultural gross output value is easy to be available among the limited amount of data. Data used for agricultural growth rate in the following analysis are all collected from the research data by Justin Lin (Justin Lin, 2008, p.28).

\section{The evolvement process of agricultural land system in China after its founding and corresponding agricultural efficiency}

After the founding of PRC, China implemented three agricultural land systems in succession, namely, private land ownership, rural collective land system and rural household contract responsibility system. The first system, private land ownership (1947-1952), was established at the national land meeting in 1947 before liberation. The private land ownership system of "land to the tiller" stimulated enthusiasm of farmers in production and 
agricultural efficiency was highly increased. In 1952, the total agricultural output value and the total grain output value respectively increased by $48.5 \%$ and $42.8 \%$ compared to that in 1949 . The second system was rural collective land system. Since 1952, in order to guarantee implementation of the heavy industry strategy in China, the country conducted a series of agricultural system reforms in the agricultural field in such resources as man power and land in rural areas, with the center of collectivized agricultural land system, including mandatory production plans, state monopoly over purchase and marketing of goods, prohibition to transport for sale over a long distance and limitation to free trade, etc. At the initial stage of collectivization, namely, the stage of mutual aid team and elementary agricultural producers' cooperative from 1952 to 1958, agricultural output increased for years on end. For example, the total agricultural output in 1958 increased by $27.8 \%$ compared with that in 1952 , and the average growth rate per annum between 1953 and 1958 was $4.17 \%$. At the end of 1958 , agriculture stepped into the stage of advanced agricultural producers' cooperative, and the collectivization reform plan of socialism was finished. From 1959, agricultural production declined substantially. For example, the agricultural output from 1960 to 1962 was all lower than that in 1952. Since 1963, agricultural began to enter a recovery growth period. Until 1964, the total agricultural output hadn't attained the level in 1958, and the average agricultural growth rate per annum from 1966 to 1978 was merely $2.29 \%$. The third system, namely, rural household contract responsibility system, appeared in Anhui and Sichuan, etc, in 1978. After its legal position was formally established by the Central Government in 1980, this system greatly stimulated enthusiasm of producers, promoted the increase of agricultural efficiency by a large margin, and laid a firm foundation for the overall economic reform in China in the future.

According to the situation of changes of agricultural growth rate, the effective agricultural land system after the founding of PRC included the agricultural land systems of the four periods: respectively, private land ownership system before 1952, the mutual aid team and elementary agricultural producers' cooperative system between 1953 and 1958 when the collective land system was implemented, the period between 1963 and 1967 when the production distribution right was transferred to the production team and the rural household contract responsibility system after 1978. Agricultural productivity growth at other periods was all lower than the development level before and after, and the corresponding agricultural land systems implemented were also regarded as inefficient agricultural land system.

\section{Analysis on characteristics of effective agricultural land system in China after the founding of PRC}

The effective agricultural land systems of the four periods mentioned above have three common characteristics, that is, generation due to competitive factors, effective supervision mechanism in the process of implementation and effective assets right of farmers.

\subsection{Root cause for implementation of effective agricultural land system in China --- analysis based on the "State Theory" of North}

According to North (Douglass North, 1992), one of original intentions for a ruler to enforce a system is constraint of competition. That is to say, a ruler always has competitive rivals who pose threat to the ruling security of the ruler, while the ruling security of the ruler comes from support of his voters. As for the voters, their support to the ruler rests with comparison between their support profit and support cost. Under the circumstance when their support cost is unchanged, the more their profit gained from their support to the ruler, the more support they give to the ruler. Out of consideration of the ruling security, the ruler may make some arrangements about the property rights to increase the support profit of his voters. The root cause for effective agricultural land system in China can be explained by the State Theory of Douglass North. In 1947, the Communist Party of China established the private land ownership system of "land to the tiller" in the liberated areas. Afterwards, farmers acquired land, which mobilized greatly their enthusiasm in production, improved the living standard of farmers and naturally increased the degree of recognition and support o the Central Government. Then, farmers displayed high enthusiasm in joining in the army. In the meantime, implementation of this system largely reduced relevant transaction costs (such as, compared with other agricultural land systems, privatization can economize expense of supervision or expense of cooperation). The profits farmers obtained from the land were directly linked up with the costs they expended, which, without doubt, largely facilitated improvement of agricultural efficiency. Another agricultural land system enforced as a result of competitive constraints was the adjustment of policy between 1962 and 1965. At that time, under the background of "the natural disaster of three years" between 1959 and 1962, "the serious famine had already spread and the economic crisis was escalated to the political crisis which challenged right of the decision makers and legality of the government" (Zhou Qiren, 1995). At that time, the country temporarily cancelled the distribution system with the people's commune as the calculation unit, and converted the production team into the calculation unit, which strengthened the supervision mechanism among farmers, stimulated their enthusiasm in production and 
promoted development of production. The effective agricultural land system above based on competitive constraint all promoted increase of productivity.

\subsection{Effective supervision mechanism}

According to Economics theory, people in the economic activities are with rationality, and the rational economic entity may make response to stimulation from the outside and decide their actual input in economic activities. The actual input of agricultural producers in the production process includes the material elements input into production and the actual efforts they have made. As for the production entity, only if they link up the actual efforts with their profits, can they "be recompensed according to the amount of labor expended". That is, only if supervision on labor is complete, can producers bring their enthusiasm in production into full play. In the cases of private land ownership system and the rural household contract responsibility system, when other conditions are unchanged, since the profits of laborers depend on their actual input, which, from the perspective of management theory, means that self supervision is complete and there is no need to employ other supervision systems. Thus, private land ownership system and household contract responsibility system can fully mobilize enthusiasm of producers in production. These effective agricultural land systems can economize expenses of supervision, etc, with low cost of operation. Meanwhile, the self supervision mechanism of laborers can also stimulate enthusiasm in production, have the effect of supervision and increase agricultural productivity. However, in the workpoint system of collective economy, profits of laborers depended on the workpoint, but not on the actual efforts they made. Therefore, what the supervision mechanism in collective economy ought to resolve was to unify workpoints (the quantity expended) with the actual efforts they made (the quality expended), so as to enable workpoints to really reflect the actual efforts producers made. This depended on the degree of supervision on laborers. The higher the degree of supervision, the more possibly the workpoints could really reflect the actual efforts producers made and the enthusiasm of producers could be mobilized. However, as a result of the following two reasons, the supervision mechanism in collective economy was out of validation. Firstly, compared with other industries, agricultural production has the characteristics of large production space, long production cycle and difficulty in division of labour, etc, which decide high cost in supervision on labour in agricultural production. Secondly, as for supervisors with bounded rationality, if the cost of implementation of supervision was linked up with the profits they obtained, then they would have high motive to conduct sufficient supervision to make the quantity expended by laborers equal to the quality expended. However, the actual supervisors in the rural collective economic activities in China are first-level cadre who haven't been listed in the formal administrative rank sequence of the nation and have no stimulation for promotion in the administrative rank. In the meantime, the distribution system in the collective economy also had no means to enable supervisors to obtain surplus of production. That is, the economic motivation of supervisors was not enough. Under such a circumstance, it was not enough for the simulation mechanism in the collective economy to stimulate the enthusiasm of supervisors. Generally speaking, in the collective economic system, from the perspective of producers, it is required vigorous supervision to guarantee stimulation to production. However, in the situation when supervision and stimulation on supervisors is insufficient, supervisors may provide less supervision. Thus, the stimulation mechanism under the collective economic system is out of operation (Zhou Qiren, 1997).

\subsection{Continuous expansion of assets right possessed by farmers in the real meaning}

According to definition by Yoram Barzel on property right (Yoram Barzel, 1997), it means "property right of an individual to assets is constituted by consumption of these assets, obtaining income from these assets and rights or power to abalienate these assets." The agricultural system of farmers refers to the fact that, farmers can input the production factors they possess into production activities to obtain income and obtain transfer income to abalienate these production factors. The right of farmers to obtain income by inputting the production factors they possess into production activities depends on the degree to which farmers own the following rights, including, (1) right of independent management and decision making, namely, the right to decision making of the production process, such as what kind of crops to plant, and the right to rationally distribution production factors, such as employment of laborers and return on assets; (2) profit of labor, namely, the right to share stimulation of the external aspects to production and right of product sales, etc. Under the private land ownership system and rural household contract responsibility system, farmers possessed relatively sufficient assets rights. For instance, under the private land ownership system, farmers owned the property in land in its real meaning, including the decision making of production and right of disposal on land; under the household contract responsibility system, farmers owned relatively complete right to the contracted management of land. However, under the agricultural collective system, the power of the country gradually penetrated into the property in land of farmers. In this process, rights of farmers were gradually shrunk. For example, at the stage of mutual aid team, farmers still owned the right in the sense of private land ownership except that they concentrated such factors of labor force, 
farm tools and livestock, etc, of all households in the busy season. At the stage of elementary agricultural producers' cooperative, in which the household assets of 20 to 30 families were combined together based on a unified plan, net income of farmers came from two aspects: firstly, sharing out bonus based on assets of land, livestock and farm tools, etc, and secondly, sharing out bonus based on labor input. In the meantime, production index of each household was prescribed, such as, fixed quotas for purchasing and marketing, prohibition to flow of such factors as labor force and funds, and limitation to free trade, that is, restraint set to usage of farmers' property right, their profit and transfer, but without cancelling their property in land. At the stage of advanced agricultural producers' cooperative, all production factors were collectivized, including collectivization of all agricultural production factors, such as land, livestock and labor force, etc, and income of a family merely came from the income of workpoints of the family members (Zhou Qiren, 1997). "So far, the country has demolished the fence of property right of rural society, and administrative power begins to penetrate into rural areas in an all-round way". The above analysis can push us to come to the following conclusion: the more possibly peasant households possess the proprietary right in its real meaning, the higher the production enthusiasm of farmers, the larger the agricultural performance, and the more effective the agricultural land system. Agricultural performance changes in the same direction with the degree of soundness of proprietary right of peasant households.

\section{Conclusion}

After the founding of PRC, effective agricultural land system in China was generated under push of the national strength. In an effective agricultural land system, the production subjects have such property rights in their true meaning as the right to earning of production factors and power of alienation, etc, which have internal incentive mechanism and can stimulate enthusiasm of producers so as to achieve good agricultural performance. Just as Douglass North has stated about the relationship between system and organization in his analysis on causes for large gaps between economic performances under different systems in the history (Douglass North, 2008). That is, the interaction between system and organization determines direction of institutional change, and a system determines opportunities to survive in a society. People build up various organizations in order to make full use of these opportunities. If a basic institutional framework can strengthen stimulation for the organization to participate in productive activities, then the economic activities of the organization which pursues maximization of profits may promote good economic performance. Thus, it is the center for China to achieve good agricultural performance to establish a good system and construct a sound organization.

At the time when the basic influence of agricultural land system on agricultural efficiency is fully recognized, it should also be noticed that factors outside agricultural land system also have effects on agricultural development, including policies of support to agricultural infrastructure, investment in rural education and improvement of rural environment, etc. Furthermore, the lower the productivity level, the more effects agricultural land system has on agricultural productivity, and the higher the productivity level, the more advanced the society. Factors outside agricultural land system is playing a more and more important role, which has been verified in the process of development of agriculture in developed countries (Lin Shanlang, 1999).

\section{References}

Douglass C. North. (1992). Structure and change in economic history. The Commercial Press.

Douglass C. North. (2008). Institution, Institutional Change and Economic Performance, translated by Hang, Xing. Shanghai: Gezhi Publishing House, Shanghai Joint Publishing Co., Ltd \& Shanghai People's Publishing House, October.

Justin Lin. (2008). Institution, Technology and Agricultural Development in China. Shanghai: Gezhi Publishing House, Shanghai Joint Publishing Co., Ltd \& Shanghai People's Publishing House, April.

Lin, Shanlang. (1999). Study on Chinese Rural Land System and Efficiency. Beijing: Economic Science Press.

Yoram Barzel. (1997). Economic Analysis of Property Rights, translated by Fei, Fangyu \& Duan, Yicai. Shanghai: Shanghai Joint Publishing Co., Ltd \& Shanghai People's Publishing House, June.

Zhou, Qiren. (1995). Reform in Chinese Rural Areas: Changes of Relationship between the State and Property in Land. HongKong: Chinese Social Sciences Quarterly, No. 6. 